\title{
Microbial Consortium: Effect on Horticultural Performance of Tuberose (Polianthes tuberosa L.) cv. Phule Rajani
}

\author{
Swapnil Ashok Kore ${ }^{1^{*}}$, A. M. Tirmali ${ }^{2}$, C. D. Badgujar ${ }^{3}$ and A. C. Jadhav ${ }^{3}$ \\ ${ }^{1}$ Shri Krishna Hsg. Soc. Hanumannagar, Tamhanevasti, Chikhli, Pune, \\ Maharashtra, India- 411062 \\ ${ }^{2}$ Department of Plant Pathology and Agricultural Microbiology, \\ College of Agriculture, Pune, India \\ ${ }^{3}$ Mahatma Phule Krishi Vidyapeeth, Maharashtra State, India \\ *Corresponding author
}

\section{A B S T R A C T}

\begin{abstract}
Keywords
Azotobacter,

PSB, KMB, RDF,

Tuberose,

Phule Rajani

Article Info

Accepted:

07 August 2020

Available Online:

10 September 2020

In present investigation, the effect of Azotobacter, PSB and KMB consortium on the growth and yield of tuberose (Polianthes tuberosa L.) $c v$. Phule Rajani was tested with graded levels of recommended dose of fertilizers (RDF) during kharif, 2019-20 at NARP, Ganeshkhind, Pune. The results revealed that the consortium of Azotobacter, PSB and $\mathrm{KMB}+100 \%$ RDF was found to be the most effective for number of days for spike emergence ( 88.00 days), number of days for basal floret opening (98.60 days), highest number of florets per spike (50.70), maximum length of florets $(6.17 \mathrm{~cm})$, maximum fresh weight of 100 florets $(91.27 \mathrm{~g}$ ), maximum spread of florets $(5.07 \mathrm{~cm})$, number of spikes per plant (7.77), number of bulbs produced per plant (8.87), loose flower yield $\left(6.77 \mathrm{t} \mathrm{ha}^{-1}\right)$ and bulb yield $\left(13.83 \mathrm{t} \mathrm{ha}^{-1}\right)$. This treatment was at par with inoculation treatment Azotobacter, PSB and KMB consortium $+75 \%$ RDF for the foresaid growth, durational and yield parameters.
\end{abstract}

\section{Introduction}

Tuberose (Polianthes tuberosa L.) from the Amaryllidaceae family, is one of the most popular ornamental plant of tropical and subtropical regions and produces attractive, elegant and fragrant flowers. It is cultivated for production of long lasting flower spikes. Tuberose is an important commercial cut as well as loose flower crop. Flower spikes have varied uses in bouquets and vases, while loose flowers are used for extraction of essential oil, making garlands and also other floral arrangements. Tuberose blossoms throughout the year.

Changes in crop cultivation practices along with modern crop management practices especially application of chemical fertilizers, has found to have greater adverse effect on the activity of soil microorganisms. The use of chemical fertilizers has exhibited 
detrimental effects on agro ecosystem thereby harming humankind and animals.

In view of this context, it was recommended to use biofertilizers and organic manures in an integrated manner to enhance and improve plant nutrient supply and attain sustainable crop production (Han et al., 2006).

Similarly, the continuous use of chemical fertilizers creates an imbalance among the beneficial activities of microorganisms and thereby indirectly affects the biological properties of soil. Application of biofertilizers containing beneficial microbes promotes crop productivity.

Using biological and organic fertilizers, a low input system can help to achieve sustainability of farming (Itelima et al., 2018). Tuberose requires $300 \mathrm{~kg} \mathrm{~N}, 200 \mathrm{~kg} \mathrm{P}_{2} \mathrm{O}_{5}$ and $300 \mathrm{~kg} \mathrm{~K} \mathrm{O}_{2} \mathrm{O}$ for its normal growth.

It becomes important to use biofertilizers in order to sustain soil productivity with minimized inputs to increase crop production. With this view, the present study was undertaken.

\section{Materials and Methods}

A field experiment was conducted during kharif, 2019 at the NARP, Ganeshkhind, Pune. The tuberose variety Phule Rajani was used. In all there were eight treatments replicated three times in Randomized Block Design.

The plant spacing was $30 \mathrm{~cm} \mathrm{X} 30 \mathrm{~cm}$. The recommended fertilizer dose was 300:200:300 NPK kg ha ${ }^{-1}$. The treatment details have been given in Table 1. The recommended dose of FYM @ 50t/ha was applied to all the treatments studied except absolute control. The bulbs of Phule Rajani of 3-5 cm diameter were planted at a depth of $5-7 \mathrm{~cm}$. The cultural operations like irrigation, weeding were uniformly carried out to all treatments.

For recording observations, five plants per plot were randomly selected and tagged.

The observations on durational attributes like days taken for spike emergence, for basal floret opening, floral attributes like number of florets per spike, length and spread of florets, number of spikes per plant, fresh weight of 100 florets, number of bulbs per plant, loose flower yield and bulb yield per hectare were taken and recorded.

The data recorded was subjected to statistical analysis as per guidelines given by Panse and Sukhatme, 1985.

\section{Results and Discussion}

From the data recorded in Table 1, revealed that the treatment $\mathrm{T}_{2}$ i.e. inoculation with Azotobacter, PSB and KMB consortium + $100 \%$ RDF was found most effective than rest of the treatments as it recorded its superiority for early emergence of spike (88 days), least days for opening of basal floret (98.60 days), significantly maximum number of florets per spike (50.70), maximum length of florets $(6.17 \mathrm{~cm})$, maximum spread of florets $(5.07$ $\mathrm{cm})$ maximum fresh weight of 100 florets $(91.27 \mathrm{~g})$, more number of spikes per plant (7.77), more yield of loose flowers $\left(6.77 \mathrm{t} \mathrm{ha}^{-}\right.$ $\left.{ }^{1}\right)$, more number of bulbs per plant (8.87) and bulb yield per hectare $\left(13.83 \mathrm{t} \mathrm{ha}^{-1}\right)$. This treatment was found on par with $\mathrm{T}_{3}$ i.e. Azotobacter, PSB and KMB consortium + $75 \%$ RDF.

The earliness in spike emergence and basal floret opening may be attributed to the fact that biofertilizers alone and in combination with inorganic fertilizers supplies nutrients to plants. Similar findings were reported by Dalave et al., (2009). 
Table.1 Effect of inoculation of Azotobacter, PSB and KMB consortium under graded levels of recommended dose of fertilizer on flowering and yield attributes

\begin{tabular}{|c|c|c|c|c|c|c|c|c|c|c|c|}
\hline $\begin{array}{l}\text { Sr. } \\
\text { No. }\end{array}$ & Treatment details & $\begin{array}{l}\text { Number of } \\
\text { days taken } \\
\text { for spike } \\
\text { emergence }\end{array}$ & $\begin{array}{c}\text { Number of } \\
\text { days taken } \\
\text { for basal } \\
\text { floret } \\
\text { opening }\end{array}$ & $\begin{array}{l}\text { Number } \\
\text { of florets } \\
\text { per spike }\end{array}$ & $\begin{array}{l}\text { Length } \\
\text { of } \\
\text { florets } \\
(\mathrm{cm})\end{array}$ & $\begin{array}{c}\text { Fresh } \\
\text { weight of } \\
100 \\
\text { florets }(g)\end{array}$ & $\begin{array}{l}\text { Spread } \\
\text { of } \\
\text { florets } \\
(\mathrm{cm})\end{array}$ & $\begin{array}{l}\text { Number } \\
\text { of spikes } \\
\text { per plant }\end{array}$ & $\begin{array}{l}\text { Number of } \\
\text { bulbs } \\
\text { produced } \\
\text { per plant }\end{array}$ & $\begin{array}{l}\text { Loose } \\
\text { flower } \\
\text { yield } \\
\left(\mathrm{t} \mathrm{ha}^{-1}\right)\end{array}$ & $\begin{array}{r}\text { Bulb } \\
\text { yield } \\
\left(\mathrm{t} \mathrm{ha}^{-1}\right)\end{array}$ \\
\hline $\mathbf{T}_{1}$ & $\begin{array}{l}\text { Consortium of Azotobacter, PSB } \\
\text { and KMB }\end{array}$ & 99.07 & 108.60 & 40.60 & 4.97 & 82.07 & 4.10 & 5.40 & 5.93 & 4.03 & 10.23 \\
\hline $\mathbf{T}_{2}$ & Consortium + 100\% RDF & 88.00 & 98.60 & 50.70 & 6.17 & 91.27 & 5.07 & 7.77 & 8.87 & 6.77 & 13.83 \\
\hline $\mathbf{T}_{3}$ & Consortium + 75\% RDF & 89.20 & 100.47 & 49.13 & 6.03 & 89.87 & 4.95 & 7.67 & 8.43 & 6.50 & 13.57 \\
\hline $\mathbf{T}_{4}$ & $\begin{array}{l}\text { Azotobacter }+75 \% \text { recommended } \\
\mathrm{N}+100 \% \text { recommended } \mathrm{P} 2 \mathrm{O} 5 \text { and } \\
\mathrm{K} 2 \mathrm{O}\end{array}$ & 94.47 & 105.47 & 43.60 & 5.30 & 84.77 & 4.41 & 6.07 & 7.43 & 5.93 & 12.33 \\
\hline $\mathbf{T}_{5}$ & $\begin{array}{l}\mathrm{PSB}+75 \% \text { recommended } \mathrm{P} 2 \mathrm{O} 5+ \\
100 \% \text { recommended } \mathrm{N} \text { and } \mathrm{K} 2 \mathrm{O}\end{array}$ & 96.47 & 106.20 & 44.47 & 5.47 & 85.87 & 4.52 & 6.20 & 7.73 & 6.03 & 12.63 \\
\hline $\mathbf{T}_{6}$ & $\begin{array}{l}\mathrm{KMB}+75 \% \text { recommended } \mathrm{K} 2 \mathrm{O} \\
+100 \% \text { recommended } \mathrm{N} \text { and } \mathrm{P} 2 \mathrm{O} 5\end{array}$ & 96.73 & 106.40 & 42.80 & 5.24 & 83.27 & 4.22 & 5.60 & 7.37 & 5.63 & 12.10 \\
\hline $\mathbf{T}_{7}$ & $100 \% \mathrm{RDF}$ & 91.93 & 103.53 & 46.87 & 5.63 & 87.33 & 4.60 & 6.50 & 7.80 & 6.13 & 13.17 \\
\hline \multirow{2}{*}{$\mathbf{T}_{8}$} & $\mathrm{SE}+$ & 0.66 & 0.62 & 0.53 & 0.05 & 0.82 & 0.04 & 0.15 & 0.15 & 0.10 & 0.09 \\
\hline & $\mathrm{CD}$ at $5 \%$ & 2.02 & 1.88 & 1.61 & 0.17 & 2.49 & 0.13 & 0.46 & 0.48 & 0.31 & 0.28 \\
\hline
\end{tabular}


The increase in number of florets per spike may be attributed to application of biofertilizers along with inorganic fertilizers; and possibly due to role of biofertilizers in atmospheric nitrogen fixation, better root proliferation, uptake of nutrients and water, enhanced photosynthetic activity and food accumulation, increased ability towards cell division which might have resulted in better plant growth and subsequently higher number of spikes and florets. The results comply with the findings of Koley and Pal (2011) in tuberose, Godse et al., (2006) in gladiolus and Gayithri et al., (2004) in statice. The improved floral characters might also be due to increased and proper availability of nitrogen, phosphorous and potassium required for flower development, fixation of nitrogen by Azotobacter. Also, PSB makes the insoluble phosphorous available by secreting organic acids, mainly Pseudomonas.

Increase in yield attributes may be due to adequate availability of nitrogen, phosphorous and potassium in combination with biofertilizers. This may be attributed to ability of biofertilizers to produce growth promoting substances like IAA, vitamins and riboflavin etc. which might have helped to increase yield parameters. The results are in close agreements with the findings of Chaudhary (2007) who reported increased number of bulbs per plant when inoculated with biofertilizers (Azotobacter, PSB and VAM) and graded levels of nitrogen and phosphorous in tuberose. Koley and Pal (2011) also reported that biofertilizers may be incorporated into the nutrient schedule of tuberose to obtain a sustainable production.

In conclusions the results from the present investigation revealed that inoculation with consortium of Azotobacter, PSB and KMB+ $100 \%$ RDF was found to be the most beneficial in ameliorating various growth and floral parameters and getting higher loose flower and bulb yield in tuberose. Thus, it can be concluded that the biofertilizers in a consortium may be incorporated into the nutrient schedule of tuberose to obtain a sustainable production.

\section{Acknowledgements}

The authors wish to thank Head, Department of Plant Pathology and Agricultural Microbiology Section, College of Agriculture, Pune and Faculty members of NARP, Ganeshkhind, Pune for their valuable encouragement and kind assistance.

\section{References}

Chaudhary, S. V. S. 2009. Effect of biofertilizers with nutrient and phosphorous on sprouting of bulbs and flowering in tuberose (Polianthes tuberose L.) cv. Double. Prog. Agri. 9(2): 277-281.

Dalave, P. D., Mane, S. V. and Nimbalkar, R. R. 2009. Effect of biofertilizers on growth, flowering and yield of gladiolus. Asian J. of Hort. 4(1): 227229.

Gayithri, H. N., Jayaprasad, K. V. and Narayanaswamy, P. 2004. Response of biofertilizers and their combined application with different levels of inorganic fertilizers in statice (Limonium caspia). J. of Ornamental Hort. 7(1): 70-74.

Godse, S. B., Golliwar, V. J., Chopde, N., Brahmankar, K. S. and Kore, M. S. 2006. Effect of organic

manures and biofertilizers with reduced doses of inorganic fertilizers on growth, yield and quality of gladiolus. J. of Soils and Crops. 16(2): 445-449.

Han, H. S. and Lee, K. D. 2006. Effect of coinoculation with Phosphate and Potassium solubilising bacteria on 
mineral uptake and growth of pepper and cucumber. Plant Soil Environ. 52: 130-136.

Itelima, J. U., Bang, W. J. and Onyimba, I. A., Sila, M. D. and Egbere, O. J. 2018. A review: biofertilizers; a key player in enhancing soil fertility and crop productivity. J. Microbiol Biotechnol. Rep. 2(1): 22-28. inorganic fertilizer \& biofertilizer on growth and flower yield of tuberose (Polianthes tuberosa L.) cv. Prajwal in the plains of West Bengal. $J$. of Crop and Weed. 7(2): 241-243.

Panse, V. S. and Sukhatme, P. V. 1985. Statistical Methods for Agricultural Workers, ICAR, New Delhi.

Koley, S. and Pal, A. K. 2011. Response of

\section{How to cite this article:}

Swapnil Ashok Kore, A. M. Tirmali, C. D. Badgujar and Jadhav, A. C. 2020. Microbial Consortium: Effect on Horticultural Performance of Tuberose (Polianthes tuberosa L.) $c v$. Phule Rajani. Int.J.Curr.Microbiol.App.Sci. 9(09): 537-541. doi: https://doi.org/10.20546/ijcmas.2020.909.068 